\author{
М.В. Турилова \\ (Россия, Тула) \\ mariaturilova@mail.ru
}

\title{
СПОСОБНОСТЬ ЧУВСТВЕННО ВЗАИМОДЕЙСТВОВАТЬ С ВНЕШНИМ МИРОМ КАК ХАРАКТЕРИСТИКА УМСТВЕННОГО И ПСИХИЧЕСКОГО СОСТОЯНИЯ ЧЕЛОВЕКА ПО ДАННЫМ СЛАВЯНСКИХ ЯЗЫКОВ*
}

В работе предложено описание фрагмента лексико-семантического поля «Безумие», ограниченного моделями, связанными с признаком способности к чувственному взаимодействию с внешним миром и идеей нарушенного, ограниченного восприятия, по данным славянских языков. Рассмотрены этимологические гнезда *(j)av-, *bliskati / *blistati, *gluxъ, *glums, *glupъ, *maxati, *majati, *mamiti, *maniti, *mara, *matati, *muniti, *mbniti, *mbrk-, *němъ, *nokt'-, *slěpъ, *torp-, *tъlm-, *tьma, *mbgliti, *umъ.

Установлено, что ясность, открытость, бодрость воспринимаются как признак ума, здравого рассудка, а семантика помешательства развивается у обозначений утраты или нарушения видов восприятия ('потеря чувств, бесчувственность', 'когнитивная перегрузка, нарушение восприятия, помутнение сознания', 'закрытость, лишение возможности нормально воспринимать', 'глухота', 'слепота', 'немота, невнятная речь', 'глупость') и их предполагаемых причин ('шуметь, кричать, оглушать', 'дико себя вести', 'мерещиться', 'темнеть, помрачать', 'мутить, морочить', 'обманывать'). Предложен этимологический комментарий для русск. пск., смол. отлумитть, укр. диал. яви́да, яведрик.

Ключевые слова: этимологическая реконструкция, этимологическое гнездо, праславянский язык, мотивационная модель, лексико-семантическое поле, славянские языки, виды восприятия.

В статье анализируется лексика лексико-семантического поля «Безумие» в славянских языках в пределах моделей, связанных с признаком способности к чувственному взаимодействию с внешним миром и идеей нарушенного, ограниченного восприятия. Рассмотренные слова и этимологические гнезда исследованы в работаx [Molnár 1985], [Orel], [Wojtyła-Świerzowska 1991], [Амелина 2008], [Белетич,

* Я благодарю проф. Ж. Ж. Варбот за внимательное чтение статьи и замечания , О. М. Сергееву за помощь при доработке статьи. 
Лома 2013], [Варбот 2012], [Валенцова 2013 а; 2013 б], [Виноградов 1994], [Виноградова 2013], [Журавлев 2006; 2013], [Леонтьева 2007], [Мельникова 2012], [Меркулова 1975; 1989], [Петлева 1975], [Толстая 2008], [Турилова 2010], [Ясинская 2013] и других.

При этимологической реконструкции учитывается наличие продолжений праславянских лексем с искомыми значениями по крайней мере в двух славянских языках разных подгрупп и архаичность словообразовательных, мотивационных моделей. Для диалектных праславянских лексем с искомыми значениями указываются изоглоссы.

Рассмотрим сначала семантику «противоположного» понятия. Праслав. *uтъ восходит к и.-е. *au-men- 'ясное сознание', 'бодрствование', 'способность замечать, узнавать, познавать', 'ум, рассудок' с корнем *au-, *auēi- 'чувственно воспринимать, понимать' [Pokorny 78]. Лексемы с этим корнем в индоевропейских языках обозначают грани чувственного восприятия: зрение (санскр. ávih 'зримый', $\bar{a} v i s$ 'явный'), слух (лат. audiō 'слышать, слушать' из *auis-dh-), осязание (греч.

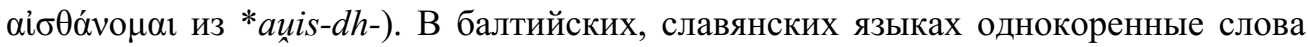
называют мыслительную деятельность как состояние бодрствования, адекватного восприятия (лит. aumenis 'память', ovis 'бодрствуя', ovyje 'наяву', русск. ум 'ум') [Цыганенко 449]. В современных славянских языках слова с корнем ум- с отрицательными префиксами и словосочетания с глаголами утраты обозначают сумасшествие, ср. русск. лиши́ться ума́, русск. говоры Низовой Печоры умо́м поплени́ться 'сойти с ума' [СРНГ 47: 162].

К тому же индоевропейскому корню восходят праслав. сущ. *ava, *avo, нареч. *avě, глагол *aviti (se) и образованное от него сущ. *avъ. Исходным значением праслав. * $a v$-, вероятно, является 'чувственно воспринимать'. Основной - семантика зрительного восприятия: 'явиться, сделаться видимым' (ст.-слав. авити / навити (сл) 'явиться, показаться, открыться', макед. ја̄ви се 'то же', с.-хорв. ја́вити ce 'то же') и 'показать, открыть' (ст.-слав. авити / гавити 'явить, открыть, показать', болг. авя, явя 'то же', чеш. jeviti 'проявить, показать', польск. редк. jawić 'то же', др.-русск. русск.-цслав. явити, русск. стар. явйть 'обнаружить, показать', укр. яви́ти 'то же').

Зрительное восприятие связывается с познанием: 'сделаться известным, открыться' (словен. jóviti se 'явиться, дать о себе знать', чеш. jeviti se 'то же', слвц. javit' (sa) 'то же', польск. редк. jawić się 'то же', ст.-слав. авъ 'видно, ясно, известно', русск. явныгй, укр. явний, блр. яўны 'явный, известный, очевидный').

Следом появляются обозначения речи: 'сообщить' $\leftarrow$ 'явить, показать, открыть' (болг. явя 'сообщить, окликнуть', макед. ја̄ви 'то же; заявить, донести', с.-хорв. jóвити 'объявить', словен. jóviti ‘то же', н.-луж. jawiś ‘то же', словин. jāvjüc 'то же', др.-русск. русск.-цслав. явити 'то же'). К значению речи в представлениях о человеке обратимся чуть позже.

На основе исходного 'способность воспринимать' развиваются значения 'бодрствование' (с.-хорв. jâv ж.р. 'явь, бдение', кашуб.-словин. tiava 'то же'), 'ясность ума' (русск. яв в выражении на яву 'в полном, здравом уме, в бодрствующем 
состоянии') и, вероятно, на основе семантики зрительного восприятия, 'ясность, свет’ (чеш. стар. јav 'свет, ясность, явность', слвц. јavný 'явный, ясный, видимый’) и далее ‘мир’ польск. na jaw ‘на свет Божий’ [ЭССЯ 1: 93-95; 99-100].

Некоторые слова сохраняют этимологическое значение корневых морфем, указывающее на родство *um- и *(j)av-: др.-русск. разумъ / розумь 'указание, знак' [Срезневский III: 160], рус. диал. на яву́ 'в полном, здравом уме, в бодрствующем состоянии' [ЭССЯ 1: 99]. Арх. не́у́м ‘безумие, сумасшествие’ представляет модель 'без ума' $\rightarrow$ 'сумасшествие' или, с учетом не́у́м иркут., перм., урал., сиб., кемер. 'бессознательное состояние', арх. в не́уме, не́ум взял, перм., урал. не́ум нахо́дит 'об истерическом припадке, временной потере сознания', кузбасск. не́умь 'отупление, оцепенение' [СРНГ 21: 193], 'потеря сознания, чувств, бессознательное состояние' $\rightarrow$ ‘безумие', подобно словин. иоtrwp 'психически больной человек' в гнезде праслав. *torp- 'цепенеть, застывать' (при ст.-чеш. otrapa 'дурман, оторопь', др.-русск. оторопь 'оцепенение, бесчувственность', 'утомление') [ЭССЯ 30: 195-196].

В семантической зоне «невосприимчивости» некоторые слова, называющие отсутствие того или иного вида восприятия, этимологически значат 'закрытый', 'не имеющий контактов с внешним миром, ничего не способный воспринять и сообщить'.

Прилагательные этимологического гнезда праслав. *gluxъ в славянских языках преимущественно означают глухоту. О.Н. Трубачёв возводит *gluxъ к и.-е. *k'lous'дефект, недуг' (*sluxъ, *slušati), сравнивая его вслед за Махеком с лит. glusnùs 'послушный', klùsas 'тугой на ухо, глуховатый', klausýti ‘слушать' и объединяя с лит. glùšas 'глупый', 'глухой’ [ЭССЯ 19: 146-147]. По другой версии, праслав. *gluxъ ‘неспособный слышать' Ł ‘закрытый’ восходит к и.-е. *gel- ‘давить, притеснять, закрывать’ [Wojtyła-Świerzowska 1991, цит. по Толстая 2008], ср. также значения 'потерявший голос, немой': ср. русск. диал. рязан. глухо́й 'одинокий, такой, которому не с кем слова сказать' [ЭССЯ 6: 146], болг. диал. гл'кна 'затихать, переставать плакать от истощения и потери голоса', русск. диал. подмоск. гло́хнуть 'скучать, быть в одиночестве' [там же: 157], ст.-польск. okchnáć 'становиться немым' [ЭССЯ 26: 211].

В этом гнезде есть примеры искомых нами значений: русск. диал. прибайк. «Голова загло́хла, прямо исшуме́лася» 'перестать соображать, сильно болеть (о голове)' [СПрибайк. 1: 122], ст.-чеш. hluchá петос 'падучая болезнь' [Толстая 2008: 158], при этом эпилепсия и психические заболевания часто называются одним и тем же словом.

Допускается родство и экспрессивная суффиксальная производность праслав. *glupъ и *glumъ от усеченного *gluxъ. Их продолжения и дериваты в современных славянских языках обозначают злую насмешку, издевательство и глупость, обнаруживая семантический параллелизм [ЭССЯ 6: 147-148] с исходным *gluxъ: все они называют помеху восприятию. Ср. значения 'глухой' (русск. олон. глуми́ться ‘плохо слышать', с.-хорв. диал. glûm 'глухонемой’), ‘ошибаться’ (русск. диал. пск., твер. поглуми́ть 'ошибиться, промахнуться’) [СРНГ 27: 293]. 
Слова с этим корнем *glum- имеют такие значения: 'шуметь' (др.-русск., русск.цслав. глоумъ 'забава', 'шум’, русск. диал. пск., свердл., ср.-урал. глум 'то же, громкий разговор'); ‘пустословить' (ст.-слав. глоумити сА 'хвастаться', 'пустословить', глоумлюнић 'пустословие' [Старосл. сл. 171]); 'насмехаться, издеваться’ (ст.-сл. глоумы дыгати 'высмеивать', болг. глу́ма, глу́мъ 'шутка, насмешка', русск. диал. глум 'насмешка, издевательство', пск., курск., орл., ср.-урал., олон., арх., свердл. ‘то же', укр. глум 'то же', русск. диал. глу́ма 'насмешник, глумливый', блр. глум 'шутка', болг. глу́мя се 'шутить, насмехаться', словен. glúmiti ‘то же', ст.-слав. глумити сА 'то же' [ЭССЯ 6: 148]; польск. диал. gtum 'издевательство, мучение, напасти', блр. диал. глум 'то же', польск. диал. głumić ‘издеваться, измываться’).

Производной является семантика умственной, психической недостаточности. Часто глупость и помешательство называются одним и тем же словом. Значение 'глупый' в семантике слова *glumъ представлено в основном в восточно- и западнославянских языках: словен. glúma ‘глупость, дурачество', польск. диал. głum 'то же', русск. диал. глума́ 'дураковатый, бестолковый' [Добровольский 128], глум русск. прибалт. гов. 'сумасбродство, блажь, дурь', глумо́й 'глупый, несообразительный', блр. глум 'дурь', диал. глума́к 'ограниченный человек', русск. диал. орл., курск., костр., влад., пск., ленингр., смол., калуж., новосиб. глумно́й 'глупый, бестолковый', блр. глу́мный 'то же', глу́мны 'то же' [ЭССЯ 6: 148], а также русск. глуми́ться влад. 'терять ясность сознания', пск., твер. 'одуреть, ошалеть', оглуми́ть 'оглоушить; лишить способности соображать (шумом, криком, длительным разговором )', русск. диал. орл., курск., пск., смол., тверск. оглуме́ть 'то же', курск., новг. оглумне́ть 'то же', новосиб. 'поглупеть', блр. оглуми́ц̧ьца, аглуміщ̧ца ‘одуреть, прийти в беспамятство’, ‘потерять здравый смысл’, русск. латв. гов. го́лову глуми́ть 'то же', блр. глуми́иь 'то же', блр. оглуми́йь 'то же' [СРНГ 6: 210; 22: 320; ЭССЯ 26: 208].

Лит. glùminti значит 'делать глупым, дурачить', 'расстраивать', glùmti ‘глупеть, дуреть' [Либерис 198]. Вероятно, значение потери рассудка производно от 'заморочить, сделать неспособным соображать шумом, криками’ (чеш. rozhlušiti 'pacшуметься’ [ЭССЯ 33: 88]), ‘притупить нормальное восприятие и мышление’.

Зап.-брян. оглуми́ть означает 'сильным ударом по голове лишить сознания, рассудка', первое его значение - 'оглушить, оглоушить, лишить способности соображать'. Это случай реинтерпретации слова и его экспрессивного семантического развития по активной модели 'лишить сознания, рассудка' $\rightarrow$ 'ударить (по голове)'.

Собственно семантика помешательства представлена в гнезде *glum- лишь в русском языке: глуми́ться яросл. 'беситься', оглуми́ться твер. 'лишиться рассудка’ [СРНГ 6: 210; 22: 320]. В древнерусском языке однокоренные слова означали скоморошество, которое негативно оценивалось Церковью. Его обозначения, вероятно, сблизились с названиями беснования, отсюда появление значений 'издеваться', 'насмехаться'.

В гнезде *glupъ семантика помешательства представлена праслав. *glupъ(jb), *glupiti, *glupĕti с основными значениями 'глупый', 'глупеть' (н.-луж. głupy 
'глупый, тупой, безумный, дурацкий', в.-луж. hłupjeć 'глупеть, сходить с ума', польск. gtupieć 'то же' [ЭССЯ 6: 151-152], русск. диал. арханг. заглупять 'то же' [СРНГ 10: 7]), *obglupěti (польск. ogtupieć 'то же', диал. 'то же', словин. ogtёр'ec 'то же', русск. диал. арханг. оглуnе́mь 'то же'), *obglupiti (польск. ogtupić 'то же') [ЭССЯ 26: 209]. Поскольку есть примеры обозначений отсутствия восприятия (словен. oglupéti 'оглохнуть', oglupiti 'оглушать'), можно предположить мотивацию 'закрытый'.

Таким образом, в названных этимологических гнездах *gluxъ, *glumъ, *glup семантика потери рассудка базируется на моделях 'не воспринимающий, закрытый' $\rightarrow$ 'глупый, сумасшедший', 'шуметь, издеваться, оглушать' $\rightarrow$ 'лишать рассудка', 'шуметь, дико себя вести' $\rightarrow$ 'бесноваться'.

Существуют представления и о том, что к помешательству ведет излишняя открытость: русск. диал. казан. ум не за́перm 'о неокрепшей психике у молодых людей', омск. ум разошёлся, ум расшара́шился [СРНГ 47: 161] ('неподобающе открытый' $\rightarrow$ 'сумасшедший').

В семантической структуре исследуемого поля речь относится к сфере взаимодействия с окружающим миром, в которую входят и виды восприятия. Судя по лексическим данным, в славянской картине мира способность говорить оценивается высоко, в то время как невнятная речь приравнивается к немоте, неразумию, помешательству и лишению собеседника рассудка. Модель 'немой, бормочущий, непонятно говорящий' $\rightarrow$ 'бредящий, неразумный, сумасшедший’ существует уже в праславянском языке.

Праслав. *nе̌ть(jb), *nе̌тьсь [ЭССЯ 25: 100-105] означает 'немой’ из 'бормочущий, невнятно говорящий' (др.-русск., русск.-цслав. нъмыл 'лишенный способности говорить', 'косноязычный', русск. диал. курск. немо́й 'невнятно, неразборчиво говорящий', говор казаков-некрасовцев 'молчаливый', волог. не́мыц 'плохо выговаривающий, произносящий слова'), откуда появляются значения 'глупый' (с.-хорв. nїјеm 'немой, глупый', словен. nêm, néma 'немой, глупый, неразумный'), 'иностранец' как «непонятно говорящий» (русск. не́мец) и даже 'животное, скотина' (укр. диал. німе́й язе́к) [там же: 101-102]. Мейе, Брюкнер возводят *пе̌тъ к звукоподражат. *mе̌mъ (лтш. mе̄ms, польск. диал. mіету 'немой', греч. $\mu \tilde{\mu} \mu \varsigma$ 'подражатель, актер, лицедей’), хотя О.Н. Трубачёв связывает его с глаголом jbti, *němb из *ne-еть / -jьmь [там же: 102]. Наши данные свидетельствуют в пользу этимологии «немой» из «говорящий непонятно». К тому же гнезду может относиться звукоподражат. праслав. *momotati (ст.-польск. mamotać, польск. диал. momotać, mamotać ‘говорить невнятно, бормотать' $\rightarrow$ 'околдовывать, лишать здравого смысла’) [ЭССЯ 19: 208] с корневой огласовкой -о- итеративного глагола.

Аналогично праславянское *ne-vě $(d) g o l s b$, буквально «не понимающий сказанное» (Г.А. Цыхун, А. С. Львов) [ЭССЯ 25: 67], представлено в славянских языках с семантикой ст.-чеш. nevěhlas со значением 'неразумный человек, сумасшедший', др.-русск. невъголось 'невежда', 'язычник' («Повесть временных лет», 6488 г.) [Срезневский II: 365], русск.-цслав. невъгласъ 'то же', русск. диал. невъголос 'неверующий', укр. неві́лас бран. 'невежда'. 
Немота и невнятная, непонятная речь у славян оцениваются отрицательно: например, связываются с нечистой силой [СД III: 292, 296; Журавлев 2013]. В гнезде *muniti (se) славянские продолжения означают 'грязнить', неодобрит. 'чахнуть, хмуриться', 'обманывать', ‘молчать', ‘дурак’, а семантический переход определен как 'молчаливый, немой' $\rightarrow$ 'глупый, сумасшедший': ср. болг. диал. му́ня 'молчаливый человек', мун’á ‘замкнутый человек', серб. диал. мӱь а 'несерьезный человек, вертопрах, дурак’, мо́юа 'дурак’, чеш. тийа, ти̊n̆а 'неразговорчивый человек, немой, дурак’, польск. типіа ‘лентяй, дурак, молчаливый человек’ [ЭССЯ 20: 190].

Обозначают безумие и слова, указывающие на конкретный способ лишения рассудка, искажения сознания, связанный с языческими шаманскими практиками, сопровождавшимися ритмичными звуками, движениями шамана, мерцанием света или темнотой, специфическими запахами. Целью их являлись когнитивная перегрузка, воздействие на сознание участников с целью нарушения восприятия, помутнения сознания [Меркулова 1972: 137; Амелина 2008: 94-95]. Многие такие выражения имеют синкретичную семантику (и действие, и результат).

В описаниях случаев воздействия на человека нечистой силы или измененного состояния сознания человека (к примеру, в лексико-тематической группе русских глаголов со значением 'казаться, мерещиться') зрительный, слуховой, обонятельный (разг. наню́хаться 'нюхая, дойти до болезненного возбуждения, до опьянения (наркотиками)'), осязательный (прост. Кондра́шка хвати́л 'о внезнапной смерти'), вкусовой (русск. диал. дон. объе́сться беленьи, беси́лой, бесю́ки 'обезуметь, начать вести себя подобно сумасшедшему' [СРНГ 22: 275]) каналы объединяются в рамках ментального восприятия и могут не уточняться. Первые два из перечисленных наиболее важные, зрительное восприятие доминирует [Ясинская 2013: 363-375].

У западных славян, хорватов и словенцев однокоренными словами называются мерцание огней и блуждание и души-скитальцы (кающиеся грешники или живые ведьмы) в виде блуждающих огней, сбивающих людей с пути [Виноградова 2013: 248-257]. Некоторые из этих слов называют также измененные состояния сознания: например, праслав. *nokt'bnica (н.-луж. nосnice ж.р. мн. ч. 'лихорадочный бред, бредни; лунатик (ночницы днем спят, а по ночам бродят)', ст.-польск. посnісе ‘кошмар, тяжелый сон с кошмарами и ощущением удушья' при с.-хорв. nòćnica 'ночной призрак, привидение; ночное бродяжничество', слвц. диал. nočnica 'мифическое существо, которое высасывает молоко из сосков (груди) у рожениц', ст.польск. nосnіса 'призрак, (блуждающий) огонек') [ЭССЯ 25: 179-180].

Соответственно, в пределах типа мотивации 'нарушение восприятия' $\rightarrow$ помутнение сознания человека' может быть выделено несколько моделей. Связь зрительного восприятия и потери рассудка отражает переход 'мерцать (о свете), темнеть' $\rightarrow$ 'приводить в измененное состояние сознания, сводить с ума', представленный группой глаголов со значением 'мерещиться'. Соседствуют значения 'мигать, мерцать', 'темнеть', 'сверкать, переливаться (о свете)', 'кивать головой, засыпая', 'понимать, знать', ‘бредить', 'призрак', 'обман', 'беспамятство’ и другие. Для некоторых из них семантика 'мерцать, темнеть' является первичной: праслав. *grěziti sę, *kazati sę, однокоренные *maxati, *majati, *mamiti, 
*maniti, *mara, *matati с разными суффиксальными расширениями; *melviti, *mitusiti se, *mbniti se, *mbrk'ti, *mbstiti se, *timiti se, *videti sę. Другие свидетельствуют в пользу обратимости семантических переходов, значение 'мерещиться' развивается вторично на основе 'сходить с ума': *blazniti sę, *čuditi sę, *čutiti sę, *děkati sę, *glumiti, kъrziti sę, *mъčbtati sę, *mbdbliti sę, *̌̌avěti sę и др. [Меркулова 1972: 136-141].

Иногда в гнезде действует несколько типов мотивации: например, *bliskati / *blistati $\leftarrow$ *bles- < и.-е. *bhles- 'блестеть' [Pokorny I: 158]. Серб. диал. блијѐска (праслав. *blěska) означает 'дурак, ненормальный' (из 'пораженный молнией') [ЭССЯ 2: 113-114], праслав. *blesnъ(jb) с другим суффиксом означает потерю рассудка (серб. блѐсан 'дурак, глупец, stultus', ст.-польск. blesny 'сумасшедший', словин. blesny 'сумасшедший, с помраченным рассудком', blesnï 'сумасшедший, глупый’) [там же: 109-110], модель 'блестеть, мерцать, нарушать восприятие' $\rightarrow$ 'лишать рассудка'.

В некоторых гнездах семантика тяжелого душевного состояния, недуга на основе значения 'тёмный', возможно, возникает еще в индоевропейском языке: так, русск. тьма родственно авест. təmahvant- 'ослепленный, околдованный, введенный в заблуждение', др.-в.-н. dinstar 'мрачный’ [Фасмер IV: 133-134]. Значение ‘бредить' сербохорв. диал. ма̀zлити в гнезде *mbgliti (se) производно от 'создавать туман (о пыли, дыме и пр.)', перен. 'терять ясность, становиться мутным (о глазах, зрении)', др.-русск. мәлити 'омрачать настроение' - от 'делать сумрачным' [ЭССЯ 21: 96].

В гнезде *mbrk- семантика сумасшествия производна от значений 'мрак, темнота, темный, помрачать’ и более позднего ‘мутить, морочить'. В некоторых случаях уверенно определить семантический переход нельзя. Вероятно, по модели 'мрак, темнота, темный, помрачать' $\rightarrow$ 'лишать рассудка' семантика помешательства развивается у праслав. *morčiti (se) (серб. мра́чuтu се безл. 'помрачаться, терять рассудок' при безл. 'темнеть, смеркаться', 'хмуриться, терять жизнерадостность', укр. моро́чити 'одуреть, лишать сознания', безл. обморо́чило 'помрачение ума находит’, моро́чииьциа 'то же') [ЭССЯ 19: 217], южнослав. диал. *mbrcati (с.-хорв. стар. диал. мрцати перен. 'терять сознание, помрачаться (о сознании)'), *mbrčati (с.-хорв. диал. мрхчати, ми́чати перен. 'то же') [ЭССЯ 21: 126-127], южнослав. диал. *mbrčiti (se) (болг. диал. мрчи́ безл. 'иметь замутненный ум (обычно после алкогольного опьянения)') [там же: 129], *mbrknoti / *mbrk'ti (серб. диал. мркни$m u$ 'помутиться, помрачиться (о сознании), потерять сознание') [там же: 133-135], праслав. *obmorčiti (se) (ст.-чеш. omračiti, omráčiti ‘потерять рассудок', ср. позднейшее слвц. omračit' 'лишить чувств (обычно ударом по голове)', др.-рус. ц.-слав. омрачити умь 'лишить способности ясно мыслить и рассуждать' (XII в.), омрачитися 'помрачиться, лишиться способности здраво мыслить и рассуждать' (XIV в.)) [ЭССЯ 28: 78-79], *obmorčenьje (слвц. omráčenie 'потеря сознания, вызванная ударом по голове', экспр. 'затемнение, помрачение, вызванное каким-л. сильным воздействием, состояние ужаса, страха'; рус. диал. донск. обмороче́ние 'обморок', блр. обмороче́нне, диал. обморочэ́нье ‘то же') [там же: 77]. 
Модели 'мутить, морочить' $\rightarrow$ 'лишать рассудка' соответствуют восточнослав. диал. *morkъ/a ‘безумие’ (рус. моро́ка пск., смол. 'помрачение рассудка', блр. диал. маро́ка 'то же', блр. моро́ка 'обморок, помраченье', русск. диал. костр. мо́рок ‘то же, припадок', сиб. мо́ро́к 'что-н. одуряющее, очаровывающее сознание, помрачающее рассудок', яросл. мо́рок 'припадок эпилепсии') [ЭССЯ 19: 230-232; 235-236], *obmorčiti (se) (вероятно, донск. омрачúmься 'сойти с ума' при урал. омрача́mь 'дурачить, морочить' [СРГСУ Доп. 369], укр. обморо́чити, оморо́чити 'одурить, лишить сознания', блр. обморо́чщuь 'то же', блр. диал. обморо́чыцица 'потерять сознание, упасть в обморок, помутиться (о сознании)', оморо́чыцица 'то же') [ЭССЯ 28: 78-79].

В гнездах *maxati, *majati, *mamiti, *maniti, *mara, *matati, суффиксальных образованиях от *mati 'махать рукой' из и.-е. *mā- 'махать рукой, кивать украдкой', 'морочить, обманывать', ‘колдовать' [ЭССЯ 17: 202; Pokorny I: 693; объединению гнезд воедино возражают Белетич, Лома 56-75], семантическое развитие реконструируется как 'маячить перед глазами, мельтешить' $\rightarrow$ 'морочить, обманывать; мучить, заставлять страдать' $\rightarrow$ 'сводить с ума'.

Примеры в первом гнезде - это с.-хорв. mahnit прич. субст. 'сумасшедший', укр. махоме́тник 'сумасшедший', экспресс. преобразование магомета́нин 'мусульманин', как и укр. диал. махоме́m 'разбойник', вторично сблизившееся с маха́mu и мета́mu [ЕСУМ III: 420], ср. словен. omáhati 'отлупить, поколотить', с.-хорв. omáhnuti 'обмануть', русск. прост. сленг. маха́mься 'задираться, драться', блр. омахну́йь 'проворно обмануть', обма́х ‘промах, обман’ [ЭССЯ 28: 39].

В гнезде *majati, *majačiti представлены польск. *majaczyć się перен. 'бредить, чудить' при первом значении 'мелькать', русск. диал. маячиться курск., том. 'мерещиться, казаться', новг. 'болеть, быть нездоровым') [ЭССЯ 17: 130], *majakь (польск. majak 'бредовое видение', русск. диал. сиб. маяк 'человек, молчащий и ничего не понимающий’) [там же: 131; СРНГ 16: 61].

В гнезде * mamiti это южно- и западнославянские изоглоссы: южнослав. *mama/s (хорв. mâm 'то, что приманивает', 'бешенство, неистовство', mäma 'то же', тата 'сумасшедший, взбесившийся', словен. стар. тата 'то же', ц.-слав. мамъ 'глупец') [ЭССЯ 17: 185; 190-191], *mamiti (se) (в значении 'обманывать, соблазнять, обольщать' во всех южнославянских, ст.-чешском, чешском, ст.-польском, польском, ц.-слав. языках; значение 'сходить с ума' представлено в южнославянских языках: хорв. mámiti se 'сходить с ума', словен. mámiti 'то же', чеш. mámiti ‘то же') [там же: 187-190], *mamьnъ(jъ) (ц.-слав. мамьнъ 'неразумный', хорв. стар., совр. maman, mamen 'то же, безумный', 'бешеный, разъяренный', откуда хорв. стар. mamnik 'то же', серб. маิман 'то же') [там же: 195], южно- и западнослав. *jbzmamiti с искомым значением (словен. zmámiti 'ошеломить, вывести из себя', 'одурачить', чеш. zmámiti 'то же', слвц. zmámit' ‘то же', польск. zmamić ‘заморочить, обмануть', диал. zmamić, словин. zmańic 'то же') [ЭССЯ 9: 44-45], *obmamiti (ц.-слав. омамити сА 'stultum fieri, обезуметь, стать юродивым', сербохорв. omámiti 'приманить, обмануть, испугать, довести до потери сознания’, словен. редк. omámiti, чеш. omámiti, ст.-слвц. mámit' ‘оглушить, ошеломить, одурачить') [ЭССЯ 28: 41-42], *obmamb/b/a 
(чеш. редк. отат 'умопомрачение, наваждение, галлюцинация', польск. отат 'то же', словен. ота̂ma, obmâma 'оглушенное состояние, обман, одурачивание') [там же: 42].

В гнезде *manъ семантика безумия представлена восточнослав. изоглоссой *mana (русск. диал. мана́ 'приманка, соблазн, то, что прельщает, отуманение рассудка', ‘дурь, блажь', укр. разг. мана́ 'то, что внушено злым духом’, ‘призрак, наваждение', блр. мана́ ‘то же; ложь, обман; колдовство’) [ЭССЯ 17: 195-196].

Гнездо *mara пополняет указанное поле лексикой, развивающей семантику 'безумие' на базе 'видения, бред’: *mara (ц.-слав. мара 'исступление', др.-рус. мара 'то же, потеря сознания', 'помрачение ума, забытье, сновидение', укр. мара́ 'призрак, бес, обморачивающий людей, затемняющий им рассудок, чтобы завести в опасное место' при словин. 'сновидение, привидение', блр. ма́ра 'призрак, привидение', 'ведьма, нечистая сила', полесск. мара́ 'бес', болг. диал. мара́ва 'кошмар') [там же: 204-207], *mariti (se) (польск. диал. marzyć 'размаривать, приводить в бессознательное состояние, говорить небылицы, дурачить', укр. ма́риmи 'грезить, бредить', ма́рити 'то же, что мріяти 'бредить в горячке') [там же: 207], *obmara/s (в.-луж. womara 'бессознательное, полусонное состояние', н.-луж. homara, homora 'то же; слабость; предсмертная борьба', слвц. отан 'умопомрачение, усталость'), *obmariti (слвц. omarit' 'оглушить, ошеломить', 'утомить, ослабить, лишить чувств', рус. донск. обма́рить 'лишиться сознания', укр. обмаритм ‘произвести галлюцинацию, обмануть, обморочить') [ЭССЯ 28: 46].

Однокоренными являются праслав. *komariti (se) (польск. диал. chomarzyć 'видеть во сне, бредить'), *občemerěti (укр. очеме'pimu 'одуреть, прийти в бессознательное состояние', блр. диал. ачамя'рэщь 'одуреть', *občemeriti sę ст.-слвц. očemerit'sa 'одурманиться') [ЭССЯ 26: 134-135] с архаичным префиксом *ko-/*če-.

В гнезде *matati семантика сумасшествия представлена диалектными западнои южнославянскими семантическими изоглоссами 'бредить', ‘морочить': *matoga ‘то, что морочит, лишает рассудка', ‘бес, колдун', 'шатание, блуждание', 'сновидения, грезы, мечты' (чеш. mátoha 'злой дух, страшилище, привидение; обман, сновидения', 'вертячка' (болезнь у скота), словен. matoga 'страшилище, привидение', польск. устар. matoga 'то же', польск. matocha 'колдунья'), западнослав. диал. *matožiti 'бредить; морочить, обманывать' (чеш. редк. mátožiti se 'ходить подобно привидению, бредить, грезить', диал. mátožit' 'говорить во сне, бредить, лгать, одурманивать'), *matožbnъ(jb) (чеш. mátožný 'помешанный', 'призрачный, страшный, неопределенный, как mátoha', слвц. mátožný ‘то же’, диал. mätožný ‘страшный, пугающий’), а также *matъ (русск. диал. мат новг. 'призрак, приведение', вят. мат 'дурной’, русск. диал. сев-двинск. мати́mь 'чуть-чуть виднеться, слабо отмечаться, чуть-чуть припоминаться, бредить', чеш. mátat 'страшить, пугать', польск. matać 'обманывать') [ЭССЯ 18: 6-10], *obmatati (ст.-польск. omatać ‘заморочить голову’) [ЭССЯ 28: 47].

Помешательство связывается также со слепотой. Праслав. *slěpъ от и.-е. *leip'намазывать (жиром)' (праслав. *lěpiti, *lipnoti) означает 'закрытый, замкнутый, залепленный', затем 'слепой или плохо видящий'. Продолжения праслав. *slěpъ (как и *gluxb) в славянских языках начинают обозначать отсутствие других видов 
восприятия, в том числе сопереживания, бесчувственность, безразличие и глупость [Толстая 2008: 134-174; 139].

Семантическую поддержку в исконной лексике находят относящиеся к модели 'ослепление, утрата зрения' $\rightarrow$ 'неразумие' церковнославянизмы: польск. oślepienie 'помрачение, неразумие', др.-рус. осльплениє 'помрачение', рус. смол. ослепе́ние, блр. асьляпе́ньня 'ослепление, помрачение рассудка', др.-рус. осльпитися 'лишиться разума', рус. ослепи́mь 'ввести в заблуждение', укр. осліпи́ти 'помрачать разум', осліпи́тися 'потерять способность объективного восприятия и правильной оценки чего-л.', ст.-блр. ослепити 'помрачить' при хорв. oslijèpiti, ст.-чеш. oslepiti, чеш. oslepiti, слвц. oslepit' 'ослепить, обольстить, обмануть', н.-луж. hobslěpiś ‘омрачить, прельстить’ [ЭССЯ 29: 207-209].

Итак, семантика умопомешательства развивается у обозначений утраты или нарушения видов восприятия ('потеря чувств, бесчувственность', 'когнитивная перегрузка, нарушение восприятия, помутнение сознания', 'закрытость, лишение возможности нормально воспринимать', 'глухота', 'слепота', 'немота, невнятная речь') и их предполагаемых причин ('шуметь, кричать, оглушать', ‘дико себя вести', 'зрительные помехи', 'мерещиться', 'темнеть, помрачать', ‘мутить, морочить', ‘махать рукой, кивать украдкой’, 'обманывать').

Полученные данные позволяют предложить этимологии для некоторых лексем. Укр. диал. буковин. яви́да и яведрик означают 'черт' [Гринченко IV: 534], первая лексема объясняется как *a-vid- 'призрак, привидение' от *vidéti либо *avivid- 'являющийся наяву' (Френкель, Трубачёв). Вторую Трубачёв считает табуистическим изменением первой [ЭССЯ 1: 94]. В одной из недавних работ А. Лома рассматривает как единую лексическую группу серб., болг. неведа 'сверхъестественное существо, причиняющее зло, несчастье', серб. авед, ав(uj)ecm, авет, укр. диал. я́вида, русск. диал. я́видь, лит. óvaidas. Он считает, что серб., болг. неведа, возводимое другими исследователями к *ne-věd-, происходит из позднего образования (XX в.) *дневедa $<* d$ bnevěda 'дневной призрак', варианта балтославянского * āvi-vaidas 'явный призрак', отраженного в лит. óvaidas 'страшный шалун, сорванец', серб. диал. а̀вед 'призрак, привидение, страшилище', укр. диал. я́вида 'черт', русск. диал. я́видь 'змея, которая водится в тундрах'. У балтослав. *vaida- 'призрак', подобно др.-инд. véda- 'знание, полученное от богов путем откровения', значение корня сузилось до восприятия сверхчувственного [Лома 215: 230].

В укр. диал. буковин. яведрик можно предположить сложение двух корней, *jav- (в данном случае обозначающего 'свет', то есть луну) и *der-/ *dbr- ('забирать, красть', ср. укр. де́рти, дра́ти 'разорять (гнезда)', 'брать (яйца, птенцов из гнезда, норы)', 'вытаскивать (раков)'). Само слово буквально означает 'укравший свет', что отвечает украинским легендам о черте, укравшем луну [CД II: 143-147]. Укр. диал. буковин. явида 'черт' можно считать производным с суфф. - $d$ - от явити(ся) 'быть видимым, виднеться, показаться', буквально означающим 'призрак', как и явидь 'змея, которая водится в тундрах', связанное с поверьями о том, что змеи могут оборачиваться нечистой силой в человечьем обличье, и наоборот [Валенцова 2013 б: 323-324]. 
Полученные результаты могут быть использованы в курсах историко-лингвистической, культурологической тематики, на занятиях по русскому и другим славянским языкам, при составлении словарных статей, в лексикографической и другой работе.

\section{Литература}

Buck - Buck C.D. A Dictionary of Selected Synonyms in the Principal IndoEuropean Languages. London, 1949.

Molnár - Molnár N. The Calques of Greek Origin in the Most Ancient Old Slavic Gospel Texts. Budapest, 1985.

Orel - Orel V. Russian Etymological Dictionary. Octavia and Co Press, 2007. Bb. 1, 2.

Pokorny - Pokorny J. Indogermanisches etymologisches Wörterbuch. Bern, 1959.

Wojtyła-Świerzowska 1991 - Wojtyła-Świerzowska M. Dlaczego głuchy nie słyszy? Rozważania o etymologii psł. głuchъ // Јужнословенски филолог. Београд, 1991. Књ. 47. С. 209-220.

ЕСУМ - Етимологічний словник української мови. Т. І-. / Под ред. Я. Б. Рудницкого. Вінніпег, 1962-1972.

Амелина 2008 - Амелина М. К. Генетическая характеристика слов лексико-семантического поля ‘колдовство'. Дипломная работа. М.: МГУ, 2008.

Белетич, Лома 2013 - Белетич М., Лома А. Сон, смерть, судьба (наблюдения над праслав. *mora, *mara) // Slavica Svetlanica. Язык и картина мира. К юбилею Светланы Михайловны Толстой. М.: Индрик, 2013. С. 56-75.

Валенцова 2013 а - Валенцова М.M. Мифологический аспект словацкой фразеологии // Ethnolinguistica Slavica. K 90-летию академика Никиты Ильича Толстого. С. 200-208.

Валенцова 2013 б - Валенизова М.M. Словацкие «рефлексы» общеславянской мифологической лексики // Ethnolinguistica Slavica. К 90-летию академика Никиты Ильича Толстого. С. 316-329.

Варбот 2012 - Варбот Ж. Ж. Исследования по русской и славянской этимологии. М.; СПб.: Нестор-История, 2012.

Варбот 2013 - Варбот Ж.Ж. О смысле славянского молчания // Slavica Svetlanica. Язык и картина мира. К юбилею Светланы Михайловны Толстой. М.: Индрик, 2013. С. 76-79.

Виноградов 1994 - Виноградов В. В. История слов. М., 1994.

Виноградова 2013 - Виноградова Л.Н. Души-скитальцы в виде блуждающих огней // Slavica Svetlanica. Язык и картина мира. К юбилею Светланы Михайловны Толстой. М.: Индрик, 2013. С. 248-257.

Журавлев 2006 - Журавлев А. Ф. Заметки на полях «Этимологического словаря славянских языков». II // Ad fontes verborum. Исследования по этимологии и исторической семантике. К 70-летию Жанны Жановны Варбот. М.: Индрик, 2006. 
Журавлев 2013 - Журавлев А. Ф. Фонетика бесовской речи (на восточнославянском материале) // Ethnolinguistica Slavica. К 90-летию академика Никиты Ильича Толстого. С. 344-362.

Лома 2015 - Лома А. Еще раз о призраках: во сне, наяву, в этимологии // Труды Института русского языка им. В.В. Виноградова. IV. Этимология. Гл. ред. А. М. Молдован. Отв. ред. Ж. Ж. Варбот. М., 2015. С. 230-242.

Мельникова 2012 - Мельникова С. А. Мотивационная и генетическая характеристика лексико-семантического поля «Сила, здоровье / слабость, болезнь» в русском языке. Автореф. дисс. канд. филол. наук. М., 2012.

Меркулова 1975 - Меркулова В. А. Кистории становления народной медицинской терминологии // Slawisches Wortstudien. Sammelband des internationalen Symposiums zur etymologischen und historischen Erforschung des slawischen Wortschatzes. Leipzig, 11-13. 10. 1972. Bautzen, Domovina-Verlag, [1975]. C. 132-143.

Меркулова 1989 - Меркулова В. А. Народные названия болезней (на материале русского языка). IV // Этимология 1986-1987. М., 1989. С. 7-13.

Петлева 1975 - Петлева И.П. Этимологические исследования в области сербохорватской лексики. Дисс. канд. филол. наук. М., 1975.

Толстая 2008 - Толстая С.М. Пространство слова. Лексическая семантика в общеславянской перспективе. М.: Индрик, 2008.

Турилова 2010 - Турилова М. В. Генетическая и мотивационная характеристика лексико-семантического поля «Безумие» в русском языке. Дисс. канд. филол. наук. М., 2010.

Ясинская 2013 - Ясинская М.В. «Когда кажется - креститься надо» («Обман зрения» в языке и мифологических рассказах) // Ethnolinguistica Slavica. К 90-летию академика Никиты Ильича Толстого. С. 363-376.

\section{Источники}

Гринченко - Гринченко Б. Словарь украинского языка. В 4 тт. Киев, $1996-$ 1997.

Даль - Даль В. Толковый словарь живого великорусского языка. T. I-IV. M., 1998. Воспроизв. 2-го изд.: СПб.; М., 1880-1882.

Добровольский - Добровольский В.Н. Смоленский областной словарь. Смоленск: Типография П. А. Силина, 1914.

Картотека АОС - Картотека Архангельского областного словаря. Кабинет русской диалектологии. М., филологический ф-т МГУ им. М.В. Ломоносова.

Либерис - Либерис А. Литовско-русский словарь. Вильнюс: Мокслас, 1988.

ПС - Новый польско-русский словарь / Р. Стыпула, Г. В. Ковалева. М.: Рус. яз. Медиа, 2004.

СД - Славянские древности. Этнолингвистический словарь. В 5 тт. Под ред. Н.И. Толстого. М., 1995-2012.

СДЯ - Словарь древнерусского языка XI-XIV вв. Т. I-. / Гл. ред. Р.И. Аванесов (т. I-V), И.С. Улуханов (т. VI), В. Б. Крысько (т. VII-VIII-). М., 1988-. 
СПрибайк. - Словарь русских говоров Прибайкалья. Вып. 1-4. Отв. ред. Ю.И. Кошевская. Иркутск, 1986.

СРГСУ Доп. - Словарь русских говоров Среднего Урала. Дополнения. Под ред. чл.-корр. РАН А.К. Матвеева. Екатеринбург, 1996.

СРНГ - Словарь русских народных говоров/ Вып. 1-49-. / Гл. ред. Ф. П. Филин (вып. 1-23), Ф.П. Сороколетов (вып. 24-41), С.А. Мызников (42-49-). Л., 1966-2016-.

СлРЯ XI-XVII - Словарь русского языка XI-XVII вв. Вып. 1-. М., 1975-.

Срезневский - Срезневский И. И. Материалы для словаря древнерусского языка. Т. I-III. М., 1958. Репринт издания 1895 г.

Старосл. сл. - Старославянский словарь (по рукописям X-XI веков) / Сост. Э. Благова, Р. М. Цейтлин, С. Геродес, Л. Пацнерова, М. Бауэрова и др. Гл. ред. Р. М. Цейтлин, Р. Вечерка, Э. Благова. М.: Русский язык, 1994.

Фасмер - Фасмер М. Этимологический словарь русского языка / Пер. с нем. и дополнения О.Н. Трубачёва. М., 2003. воспроизведение 1-го издания на русском языке, М., 1964-1973, T. I-IV.

Цыганенко - Цыганенко Г.П. Этимологический словарь русского языка. 2-е изд. К.: Рад. шк., 1989.

ЧРДФ - Алексеенко М.А., Белоусова Т.П., Литвинникова О.И. Человек в русской диалектной фразеологии. М.: ООО «ИТИ Технологии», 2004.

ЭССЯ - Этимологический словарь славянских языков. Праславянский лексический фонд / Под. ред. О. Н. Трубачёва. М.: Наука, 1974-2018-. Т. 1-41-.

\author{
Mariya V. Turilova \\ (Russia, Tula) \\ mariaturilova@mail.ru
}

\title{
THE ABILITY OF SENSORIAL INTERACTION WITH THE OUTSIDE WORLD AS A FEATURE OF HUMAN MENTAL AND PSYCHIC STATE ESTIMATION ACCORDING TO SLAVIC LANGUAGES
}

The article represents the description of a fragment of the lexical semantic field of madness, limited by the models connected with parameter of the ability of sensorial interaction with the outside world and the idea of imperception, blinkered vision, perception disorders, according to the data of Slavic languages. The following etymological nests are analyzed: *(j)av-, *bliskati / *blistati, *gluxb, *glumb, *glupъ, *maxati, *majati, *mamiti, *maniti, *mara, *matati, *muniti, *mbniti, *mbrk-, *němъ, *nokt'-, * slěpъ, *torp-, *tъlm-, *tbma, *mъgliti, *umъ.

It is defined that clarity, openness, vivacity are perceived as characteristics of rational mind, or sense, while semantics of madness develops by names of loss or disorders of different perception types ('loss of consciousness, feelings, unconsciousness', 'cognitive 
overload, impaired perception, impairing of people judgment and hostile effects', 'closeness, deprivation of the ability to perceive in a normal way', 'deafness', 'blindness', 'numbness, slurred speech', 'stupidity') and their suggested causes ('to make noise, to shout, to deafen', 'to act frenetically', 'to seem', 'to darken', 'to trouble, to harass', 'to deceive'. We also present etymological comments for Ukrainian dialectal яви́да, яведрик.

Key words: etymological reconstruction, etymological nest, Proto-Slavic language, motivational model, lexical semantic field, Slavic Languages, types of perception.

\section{References}

Alekseyenko M. A., Belousova G.P., Litvinnikova O. I. Chelovek v russkoy dialektnoy frazeologii: Slovar' [Man in Russian Dialectal Phraseology: dictionary]. Moscow, ITI Tekhnologii LLC Publ., 2004.

Amelina M.K. Geneticheskaya kharakteristika slov leksiko-semanticheskogo polya "Koldovstvo» [Genetic Characteristics of the Vocabulary of the Lexical-Semantic Field 'Sorcery']. Diploma thesis. Moscow: MSU, 2008.

Beletich M., Loma A. Son, smert', sud'ba (nablyudeniya nad praslav. *mora, *mara) [Dream, Death, and Destiny (Observations on Protoslav. *mora, *mara)]. Slavica Svetlanica. Yazyk i kartina mira [Slavica Svetlanica. Language and Worldview]. On the occasion of Svetlana Mikhailovna Tolstaya's Birthday. Moscow: Indrik Publ., 2013. Pp. 56-75.

Buck C. D. A Dictionary of Selected Synonyms in the Principal Indo-European Languages. London, 1949.

Grinchenko B. Slovar' ukrainskogo yazyka [Dictionary of the Ukrainian language]. In 4 vol. Kiyev, 1996-1997.

Dal' V.I. Tolkovyy slovar' zhivogo velikorusskogo yazyka [An Explanatory Dictionary of the Russian Language]. Vol. I-IV, St.-Petersburg; Moscow, 1880-1882.

Dobrovol'skiy V.N. Smolenskiy Oblastnoy Slovar' [Smolensk Region Dialects Dictionary]. Smolensk: P. A. Silin’ Typography Publ., 1914.

Etimologicheskiy slovar' slavyanskikh yazykov [Etymological Dictionary of Slavic Languages]. Eds. O. N. Trubachyev (Iss. 1-31), A. F. Zhuravlyev (Iss. 32-40). Iss. 1-40-. Moscow: Nauka Publ., 1974-2016-.

Etimologichnyy slovnik ukrajns'koy movy [Etymological Dictionary of the Ukrainian language]. Ed. in chief Y. B. Rudnitskiy. Vinnipeg, 1962-1972. Vol. I-.

Fasmer M. Etimologicheskiy slovar' russkogo yazyka [Etymological Dictionary of the Russian Language]. Ed. in chief, transl. and comm. O.N. Trubachyev. Moscow, 2003. Moscow, 1964-1973, reprint of the $1^{\text {st }}$ Russian edition. Vol. I-IV.

Kartoteka Arkhangel'skogo Oblastnogo Slovarya [Card Index of Arkhangelsk Region Dictionary]. Moscow, Lomonosov MSU, Philological faculty, Russian Dialectology laboratory.

Leont'yeva T. V. Intellekt cheloveka $v$ russkoy yazykovoy kartine mira [Human Intellect in the Russian Linguistic Picture of the World]. Ekaterinburg, 2007. 
Liberis A. Litovsko-Russkiy Slovar' [Lithuanian-Russian Dictionary]. Vil'nyus: Mokslas Publ., 1988.

Loma A. Eshche raz o prizrakakh: vo sne, nayavu, v etimologii [Once Again about Ghosts: in Dreams, in the Daylight, in the Etymology]. Proceedings of the V. V. Vinogradov Russian Language Institute. IV. Etymology. Ed.-in-chief A. M. Moldovan. Chief ed. of the issue Zh. Zh. Varbot. M., 2015. Pp. 230-242.

Mel'nikova S. A. Motivatsionnaya i geneticheskaya kharakteristika leksiko-semanticheskogo polya "Sila, zdorov'ye / slabost', bolezn'»v russkom yazyke [Motivational and Genetic Characteristics of the Lexical Semantic Field «Strength, Health / Weakness, Illness» in the Russian Language]. Thesis of the Cand. of Philol. Sciences. Moscow, 2012.

Merkulova V.A. K istorii stanovleniya narodnoy meditsinskoy terminologii [To the History of the Folk Medical Terminology Formation]. Slawisches Wortstudien. Sammelband des internationalen Symposiums zur etymologischen und historischen Erforschung des slawischen Wortschatzes [Slavic Vocabulary Studies. Proceedings of the International Symposium for Etymological and Historical Research in Slavic Lexical Heritage]. Leipzig, 11-13. 10. 1972. Bautzen, Domovina-Verlag, [1975]. Pp. 132-143.

Merkulova V. A. Narodnyye nazvaniya bolezney (na materiale russkogo yazyka). IV [The Folk Names of Diseases (based on the Russian language data). IV]. Etymology 1986-1987. Moscow, 1989. Pp. 7-13.

Molnár N. The Calques of Greek Origin in the Most Ancient Old Slavic Gospel Texts. Budapest, 1985.

Stypula R., Kovalyova G. V. Novyy pol'sko-russkiy slovar' [A New Polish-Russian Dictionary]. Moscow: The Russian language. Media Publ., 2004.

Orel V. Russian Etymological Dictionary. Octavia and Co Press, 2007. Vol. 1, 2.

Petlyeva I.P. Etimologicheskiye issledovaniya v oblasti serbokhorvatskoy leksiki [Etymological Investigations]. Thesis of the Cand. of Philol. Sciences. Moscow, 1975.

Pokorny J. Indogermanisches etymologisches Wörterbuch [The Proto-Indo-European Etymological Dictionary]. Bern, 1959.

Slavyanskiye drevnosti: Etnolingvisticheskiy slovar'v 5 tomax [Slavic Antiquities: An Ethnolinguistic Dictionary in 5 volumes]. Ed. in chief N. I. Tolstoy. Moscow: Mezhdunarodnyye Otnosheniya Publ., 1995-2012.

Slovar' drevnerusskogo yazyka XI-XIV vv. [Dictionary of the Old Russian language of XI-XIV cent.]. Eds. in chief R. I. Avanesov (vol. I-V), I. S. Ulukhanov (vol. VI), V.B. Krys'ko (vol. VII-VIII). Moscow, 1988-. Vol. I-.

Slovar' russkikh govorov Pribaykal'ya [Dictionary of Russian Dialects of Lake Baikal Region]. Ed. Yu. I. Koshevskaya. Iss. 1-4. Irkutsk, 1986.

Slovar' russkikh govorov Srednego Urala [Dictionary of Russian Dialects of the Middle Urals]. Ed. in chief memb. of the Russian Academy of Sciences Matveyev A. K. Sverdlovsk, 1964-1988. Vol. I-VII. 
Slovar' russkikh narodnykh govorov [Dictionary of Russian Dialects]. Eds. in chief F.P. Filin (Iss. 1-23), F. P. Sorokoletov (Iss. 24-45), S. A. Myznikov (Iss. 46-49-). Leningrad-S.-Petersburg, Nauka Publ., 1966-2016-.

Slovar' russkogo yazyka XI-XVII v. [Dictionary of the Russian language of the 11th17th cent.]. Moscow, 1975. Iss. 1-.

Sreznevskiy I. I. Materialy dlya slovarya drevnerusskogo yazyka [Materials for the Dictionary of the Old Russian Language]. Vol. I-III. Moscow, 1958. Reprinted version of the 2-nd Ed. (St.-Petersburg, Publ. of the Department of the Russian language and Literature of the Imperial Academy of Sciences, 1880-1882).

Staroslavyanskiy slovar' (po rukopisyam X-XI vekov) [Old Church Slavonic Dictionary (following Manuscripts of the $11^{\text {th }}-17^{\text {th }}$ cent.)] / Compiled by Blagova E., Tseytlin R. M., Gerodes S., Patsnerova L., Bauerova M. Eds. in chief R. M. Tseytlin, R. Vecherka, E. Blagova. Moscow: Russkiy Yazyk Publ., 1994.

Tolstaya S. M. Prostranstvo smysla. Leksicheskaya semantika v obshcheslavyanskoy perspektive [The Space of Meaning. Lexical Semantics in the Common Slavic Perspective]. Moscow, Indrik Publ., 2008.

Turilova M.V. Geneticheskaya i motivatsionnaya kharakteristika leksiko-semanticheskogo polya «Bezumiye»v russkom yazyke [Genetic and Motivational Characteristics of the Lexical-Semantic Field of «Madness» in the Russian Language]. Thesis of the Cand. of Philol. Sciences. Moscow, 2010.

Tsyganenko G. P. Etimologicheskiy slovar' russkogo yazyka [Etymological Dictionary of the Russian Language]. 2nd ed. Kiyev: Radyanska Shkola Publ., 1989.

Valentsova M.M. Mifologicheskiy aspekt slovatskoy frazeologii [Mythological Aspect of the Slovak Phraseology]. Ethnolinguistica Slavica. [Slavic Ethnolinguistics]. On the Occasion of Academician Nikita Ilyich Tolstoy's 90 ${ }^{\text {th }}$ Birthday. Pp. 200-208.

Valentsova M. M. Slovatskiye «refleksy» obshcheslavyanskoy mifologicheskoy leksiki [Slovak 'Reflexes' of Common Slavic Mythological Vocabulary]. Ethnolinguistica Slavica. [Slavic Ethnolinguistics]. On the Occasion of Academician Nikita Ilyich Tolstoy's $90^{\text {th }}$ Birthday. Pp. 316-329.

Varbot Zh. Zh. Issledovaniya po russkoy i slavyanskoy etimologii [Research in the Field of Russian and Slavic Etymology]. Moscow; Saint Petersburg: Nestor-Istoriya Publ., 2012.

Varbot Zh. Zh. O smysle slavyanskogo molchaniya [On the Meaning of Slavic Silence]. Slavica Svetlanica. Yazyk i kartina mira [Slavica Svetlanica. Language and Worldview]. On the occasion of Svetlana Mikhailovna Tolstaya's Birthday. Moscow: Indrik Publ., 2013. Pp. 76-79.

Vinogradov V. V. Istoriya slov [History of Words]. Moscow, 1994.

Vinogradova L. N. Dushi-skital'tsy v vide bluzhdayushchikh ogney [Wandering Spirits in the form of Wandering Lights]. Slavica Svetlanica. Yazyk $i$ kartina mira [Slavica Svetlanica. Language and Worldview]. On the occasion of Svetlana Mikhailovna Tolstaya's Birthday. Moscow: Indrik Publ., 2013. Pp. 248-257.

Wojtyła-Świerzowska M. Dlaczego gluchy nie styszy? Rozważania o etymologii pst. głuchъ [Why Gtuchy Doesn't Hear? Commentaries on the etymology of Proto-Slav. 
*gluchъ]. Yuzhnoslovenski filolog [South Slavic Philologist]. Belgrade, 1991. Iss. 47. Pp. 209-220.

Yasinskaya M. V. «Kogda kazhetsya — krestit'sya nado» («Obman zreniya» v yazyke i mifologicheskikh rasskazakh) [«When It Seems to You - You Should Cross Yourself» («Optical illusion» in Language and Mythological Narratives)]. Ethnolinguistica Slavi$c a$. [Slavic Ethnolinguistics]. On the Occasion of Academician Nikita Ilyich Tolstoy's $90^{\text {th }}$ Birthday. Pp. 363-376.

Zhuravlyev A.F. Zametki na polyakh «Etimologicheskogo slovarya slavyanskikh yazykov. II [Notes on the Margins of Etymological Dictionary of Slavic Languages. II]. Ad fontes verborum. Issledovaniya po etimilogii i istoricheskoy semantike. [To the Sources of Words. Studies in Etymology and Historical Semantics]. On the Occasion of Zhanna Zhanovna Varbot's 70 ${ }^{\text {th }}$ Birthday. Moscow: Indrik Publ., 2006.

Zhuravlyev A.F. Fonetika besovskoy rechi (na vostochnoslavyanskom materiale) [Phonetics of Speech of Evil Spirits (based on the East Slavic languages materials)]. Ethnolinguistica Slavica. [Slavic Ethnolinguistics]. On the Occasion of Academician Nikita Ilyich Tolstoy's $90^{\text {th }}$ Birthday. Pp. 344-362. 